\title{
EXPERIMENTAL POTASSIUM DEPLETION IN NORMAL HUMAN SUBJECTS. I. RELATION OF IONIC INTAKES TO THE RENAL CONSERVATION OF POTASSIUM*
}

\author{
BY RUSSELL D. SQUIRES $†$ AND EDWARD J. HUTH $\ddagger$
}

(From the Chemical Section of the Department of Medicine and the Department of Physiology, University of Pennsylvania, School of Medicine, Philadelphia, Pa.)

(Submitted for publication June 3, 1958; accepted February 19, 1959)

When healthy human subjects ingest a diet deficient in potassium but not in calories and protein, the daily loss of potassium in the urine progressively decreases (1-7). Since the daily urinary loss of ten continues to exceed the daily intake $(2,3,6)$, prompt and effective renal conservation of potassium has been questioned. Furthermore, the fecal excretion of the ion has been found to exceed the intake when the latter is low (2). But these studies do not indicate to what level the intake of potassium must fall before the renal excretion and the fecal excretion consistently exceed the intake and lead to a progressive deficit of the ion. Nor do these studies completely define the conditioning effects of intakes of other major ions on the excretion of potassium during varying degrees of potassium deprivation.

The aim of this paper is to report quantitative data describing the loss of potassium in the urine and feces of human subjects while ingesting low potassium diets and to discuss certain metabolic corollaries of the loss of potassium in urine and feces relevant to the physiological regulation of potassium excretion.

\section{EXPERIMENTAL PROCEDURE AND METHODS}

Human subjects. Fourteen balance studies were done in 11 volunteer male subjects (nine medical students and the authors). By the criteria of the medical history and physical examination every subject appeared to be in good

* This study was aided by Grant H-340 of the National Heart Institute of the United States Public Health Service and by the C. Mahlon Kline Fund of the Department of Medicine, University of Pennsylvania, Philadelphia, $\mathrm{Pa}$.

$\dagger$ Part of the work was done during Dr. Squires' tenure of a J. Allison Scott Fellowship, Department of Research Medicine, University of Pennsylvania, 1952-1953.

$\ddagger$ Part of the work was done during Dr. Huth's tenure of a Life Insurance Medical Research Fund Postdoctoral Fellowship, 1952-1953. health. However, Subject T. C. was subsequently shown by roentgen examination to have an asymptomatic duodenal ulcer.

The study design. The basic study plan consisted of a control period lasting three to eight days, and a potassium depletion period lasting six to 21 days. The duration of each study largely depended upon how long the subject could remain on the Metabolic Unit or tolerate the dietary restriction. During the control period a measured "normal diet" was ingested. Potassium depletion was studied at three levels of potassium intake: 25 to $27 \mathrm{mEq}$. per day, 14 to $16 \mathrm{mEq}$. per day, and less than $1 \mathrm{mEq}$. per day.

Experiments were designed to study, in the depletion period, the effect on urinary and fecal potassium loss of : 1) a normal or high sodium intake throughout the entire study ; 2) ingestion of sodium and potassium with chloride or with chloride and bicarbonate in a ratio of $3: 1 ; 3$ ) a low intake of $14 \mathrm{mEq}$. of sodium per day during the depletion period; and 4) progressively increasing oral doses of $\mathrm{KCl}$ to more than $300 \mathrm{mEq}$. per day in the control period.

The renal conservation of potassium and sodium was compared in separate studies in which the intake of either ion averaged $15 \mathrm{mEq}$. per day.

Potassium skin loss was not measured in our subjects; such loss of potassium during normal potassium intakes amounts to about $4 \mathrm{mEq}$. per day $(8,9)$. No correction for skin loss was made.

Subjects were allowed normal activity in the hospital and medical school during the cool fall and winter months. Studies conducted during the warm spring and summer months took place in the air-conditioned Metabolic Unit or air-conditioned portions of the hospital. Balance periods lasted 24 hours, starting at 7 a.m. The subject was awakened at that time and voided urine immediately. He was then weighed, and blood was drawn. He was then given breakfast.

Urine and stool collection. Urine was voided into a screw-capped, wide-mouthed jar large enough to hold the 24 hour specimen, as well as a measured constant amount of mineral oil and chloroform or toluol. Urine was refrigerated between voidings. Feces were collected for periods from two to eight days according to the study plan. They were passed directly into tared, wax-impregnated cardboard containers which were kept covered and refrigerated when not in use.

The stools in the depletion periods of Subjects L. P., H. F., E. H.1, E. H.2, R. S.1 and R. S. 2 were demarcated with either barium sulfate or charcoal. 
A stool-marking agent, charcoal or carmine, was given to Subjects R. A., J. B., J. D., C. P. and J. M. on their arrival on the Metabolic Unit; stool preceding this marker was discarded. The ends of the control period and the depletion period were likewise marked. Two to six day intervals were also marked during the control and depletion periods in some studies. Stool data from only these subjects were used in estimating the daily decline of the measured constituents.

Blood was drawn with minimal stasis and clotting took place under oil at room temperature. Serum was separated anaerobically.

Dietary procedure. Water was allowed ad libitum and the amount drunk each day was recorded. Subjects ingested all the food given; when possible, food was eaten from the container in which it was prepared so that the juices and small fragments of food could be completely ingested. Metabolic diets were made up from the following food sources: 1) weighed portions of previously analyzed foodstuff ; 2) commercial dialyzed milk preparations [Theralac ${ }^{\circledR}$, Lonalac ${ }^{\circledR}$ (Mead Johnson formula L.P. 412)], and fresh whole homogenized milk passed through a monobed ion exchange resin column (Amberlite MB-3) ${ }^{2}$; 3) lactose ; 4) the addition of measured quantities of $\mathrm{NaHCO}_{3}$, $\mathrm{NaCl}, \mathrm{KCl}, \mathrm{Ca}$ lactate and $\mathrm{NH}_{4} \mathrm{Cl}$ when needed as supplements; and 5) multivitamin supplements.

Subjects on diets containing about $25 \mathrm{mEq}$. potassium per day were given diets containing solid food. Those on lower potassium intakes consumed whole milk, lactose and vitamin supplemented diets. The total calories ingested were kept constant throughout each study. In a few cases nitrogen intake was reduced during the depletion period.

\section{Specific methods, chemical determinations and calculations}

Diet. Samples of homogenized, whole 24 hour diets were analyzed as well as individual samples of the foodstuff comprising this diet. Whole diet analysis was carried out periodically as a check on the summing of previous food analytical values. Agreement was satisfactory for $\mathrm{Na}, \mathrm{K}$ and $\mathrm{N} ; \mathrm{Cl}$ was somewhat variable. Diets consisting only of treated whole milk were analyzed daily.

Foods were prepared for analysis by nitric acid digestion (10), except for samples analyzed for total nitrogen by the macro-Kjeldahl method.

Chemical determinations. Sodium and potassium were determined by means of a Barclay internal standard flame photometer by the method of Wallace, Holliday, Cushman and Elkinton (10), serum chloride by the method of Franco and Klein (11) and urine chloride by the method of Harvey as described by Peters and Van Slyke (12). Urinary ammonia was measured by the method of Folin and Bell (13). Urinary titratable acidity was measured by titrating an aliquot to $\mathrm{pH} 7.4$ with $0.01 \mathrm{~N}$ sodium hydroxide using a Beckman $\mathrm{pH}$ meter to determine the endpoint, venous serum $\mathrm{CO}_{2}$ by the method of Stadie and Van Slyke (14), urine $\mathrm{CO}_{2}$ by the method of Peters and Van Slyke (12) and

${ }^{1}$ Mead Johnson formula L.P. 412 was kindly supplied by Dr. Warren Cox, Evansville, Ind.

${ }^{2}$ Amberlite MB-3 was obtained from Fisher Scientific Company, 633 Greenwich Street, New York 14, N. Y. serum and urine creatinine by the method of Bonsnes and Taussky (15). Nitrogen was determined by the macroKjeldahl method (12). Finger blood $\mathrm{pH}$ and carbon dioxide content were determined by the method of Singer and Hastings (16).

Metabolic calculations, with the few exceptions noted in the Results, were performed as previously described (17).

\section{RESULTS}

The observed data are recorded in Tables I to VIII.

\section{Renal potassium excretion during the potassium depletion period}

The daily rate of renal potassium excretion on a given day varied with the level of oral sodium intake in the depletion period and with the difference between the oral potassium intake in the control and depletion periods. Higher than normal levels of oral sodium intake tended to increase the rate of potassium excretion and lower than normal oral sodium intake may have reduced the rate of renal potassium excretion during the potassium depletion period. When the oral potassium intake was raised to three or four times the normal level during the control period the rate of renal potassium excretion was initially increased in the depletion period.

The lower the oral potassium intake during depletion the lower the daily urinary potassium content. However, the urinary potassium loss continued to be greater than the oral potassium intake when the intake fell below $14 \mathrm{mEq}$. per day for up to 21 days in one study.

1. Subjects on normal intakes of sodium (130 $m E q$. per day). In the two subjects ingesting 25 to $30 \mathrm{mEq}$. of potassium per day (Subjects T. C. and $\left.C . P_{1}\right)$, the daily rate of urinary excretion of this ion, $\mathrm{UV}_{\mathbf{K}}$, fell to a level equivalent to the intake in four to seven days. In the two different experiments on the same subject (E. H. 1 and E. H.2) ingesting $14 \mathrm{mEq}$. of potassium per day, $\mathrm{UV}_{\mathrm{K}}$ fell to 25 and $35 \mathrm{mEq}$. per day, respectively, on the fourth day and further to 19 and $27 \mathrm{mEq}$. per day, respectively, on the eighth day; in the experiment of $\mathrm{E}$. $\mathrm{H}_{2}$ the nitrogen intake was lower. In two subjects, J. D. and C. P.2 (Figure 1), ingesting less than $1 \mathrm{mEq} . K$ per day, the $\mathrm{UV}_{\mathbf{K}}$ fell to around 13 to $15 \mathrm{mEq}$. on the fourth day and $9 \mathrm{mEq}$. on the eighth day. One of these, C. P.2, was maintained for a third week on 


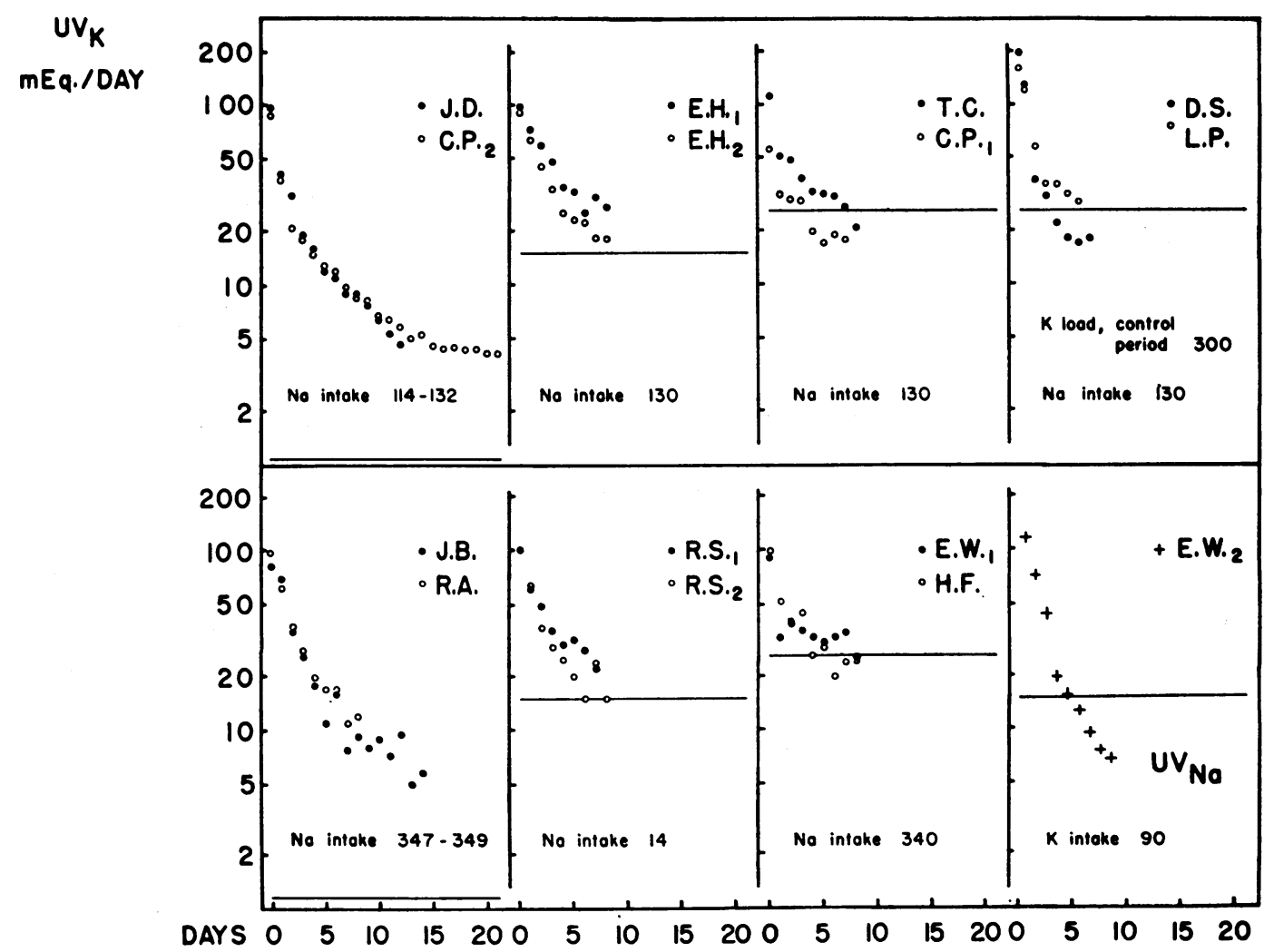

Fig. 1. The Daily Urinary Excretion of Potassium or Sodium During Depletion

The values plotted represent the daily urinary excretion of potassium in mEq., except for those of E. W.2 which are for sodium. The first value of each curve represents the subject's average daily excretion during the control period. Depletion intake values are shown by the solid horizontal lines drawn across each graph ( $\mathrm{Na}$ for E. W.2, K for the rest). Intakes for J. D., C. P.2, J. B. and R. A. were less than $1 \mathrm{mEq}$. per day. For additional detail on the diets and for discussion, see Table I and text.

potassium deprivation with further diminution of his $\mathrm{UV}_{\mathrm{K}}$ to $4.2 \mathrm{mEq}$. per day. One of these two subjects, J. D., received bicarbonate and chloride in a ratio of $1: 3$ as the supplemental anions; no difference in the excretory pattern of potassium was observed. The total cumulative amount of potassium lost in the urine showed no relation to the level of potassium intake when compared on the seventh day of depletion. At the 25 to $30 \mathrm{mEq}$. per day level of intake of potassium Subject C. P. 1 lost 138 and Subject T. C. lost $263 \mathrm{mEq}$. of potassium. Ingesting approximately $14 \mathrm{mEq}$. of potassium per day, Subject E. H. lost 305 and $232 \mathrm{mEq}$. potassium during two separate studies. Subjects C. P.2 and J. D. lost 128 and $143 \mathrm{mEq}$. potassium, respectively, while ingesting less than $1 \mathrm{mEq}$. potassium per day (Tables I and II).

2. High sodium intake ( $340 \mathrm{mEq}$. per day). In two subjects, J. B. and R. A., ingesting less than $1 \mathrm{mEq}$. $\mathrm{K}$ per day, the $\mathrm{UV}_{\mathrm{K}}$ fell more slowly, reaching $20 \mathrm{mEq}$. per day on the fourth day and $10 \mathrm{mEq}$. on the eighth day (Figure 1). Although $\mathrm{J}$. B. ingested bicarbonate and chloride in a ratio of $1: 3$ and $R$. A. ingested only chloride as the supplemental anion, the curve of $U V_{K}$ was essentially the same in these two subjects.

3. Low sodium diet (14 $m E q$. per day). The ingestion of a low sodium intake (14 mEq. per day) (R.S.1 and R.S.2) with a potassium intake of $14 \mathrm{mEq}$. per day made no significant reduction in total urinary loss of potassium when compared to a subject in a normal sodium intake, E. H.1 and E. H.2 (Figure 1).

4. High potassium diet during the control period. In two subjects, D. S. and L. P. (Figure 1), ingesting $300 \mathrm{mEq}$. potassium per day during the control period and $25 \mathrm{mEq}$. per day during the 
depletion period, the $\mathrm{UV}_{\mathrm{K}}$ declined very rapidly from an average control level of approximately $280 \mathrm{mEq}$. per day to a level of $28 \mathrm{mEq}$. by the fourth day of depletion. The high initial takeoff of the $\mathrm{UV}_{\mathbf{K}}$ curve resulted in a substantially higher urinary potassium loss during the first three days than for the subjects starting from normal levels.

5. Low sodium plus normal potassium intake. One subject, E. W.2, was placed on a diet of 14 $\mathrm{mEq}$. per day of sodium and $90 \mathrm{mEq}$. per day of potassium, following a control period, for comparison of rate of sodium conservation with a subject, R. S.2, receiving only $14 \mathrm{mEq}$. per day of each ion. Decrease in excretion rate of sodium was more rapid than that of potassium for comparable levels of intake of the respective ions; the rate of sodium conservation was enhanced by concomitant deprivation of potassium (Figure 2).

\section{Excretion of sodium and other constituents in the urine}

Urinary sodium excretion tended to decrease during the first three to four days of the period of potassium depletion and then returned to approximately the intake level of sodium. Urinary chloride excretion fell abruptly in the same period of $\mathrm{K}$ depletion, reflecting the decrease in ingested supplements of potassium chloride. Phosphate exhibited no significant variation in excretion. Urinary nitrogen excretion for the most part reflected the nitrogen intake. In two of the subjects on less than $1 \mathrm{mEq}$. potassium

TABLE I

Metabolic data on Subject C. $P_{._{2}}$ (normal $\mathrm{Na}^{+}$intake)-Intake* and urinary output of water, electrolytes, creatinine and nitrogen

\begin{tabular}{|c|c|c|c|c|c|c|c|c|c|c|c|c|}
\hline \multicolumn{13}{|c|}{ Urine } \\
\hline Day & Vol. & $\mathrm{pH}$ & S.G. & $\mathrm{Na}$ & $\mathbf{K}$ & $\mathrm{NH}_{4}{ }^{+}$ & T.A. & $\mathrm{Cl}$ & $\mathrm{PO}_{4}$ & $\mathrm{CO}_{2}$ & $\mathrm{~N}$ & $\mathrm{Cr}$ \\
\hline \multicolumn{12}{|c|}{ Control period } & $m g$. \\
\hline $\begin{array}{l}1 \mathrm{C} \\
2 \mathrm{C} \\
3 \mathrm{C} \\
4 \mathrm{C} \\
5 \mathrm{C}\end{array}$ & $\begin{array}{l}2,645 \\
2,985 \\
2,540 \\
2,240 \\
2,750\end{array}$ & $\begin{array}{l}5.38 \\
5.00 \\
5.00 \\
4.90 \\
4.88\end{array}$ & $\begin{array}{l}1.010 \\
1.009 \\
1.011 \\
1.011 \\
1.009\end{array}$ & $\begin{array}{l}143 \\
161 \\
132 \\
118 \\
122\end{array}$ & $\begin{array}{r}88 \\
100 \\
100 \\
92 \\
95\end{array}$ & $\begin{array}{l}66 \\
81 \\
85 \\
85 \\
92\end{array}$ & $\begin{array}{l}41 \\
50 \\
57 \\
55 \\
53\end{array}$ & $\begin{array}{l}206 \\
261 \\
225 \\
207 \\
229\end{array}$ & $\begin{array}{l}37 \\
40 \\
47 \\
44 \\
40\end{array}$ & $\begin{array}{l}3.7 \\
2.9 \\
2.8 \\
2.3 \\
2.8\end{array}$ & $\begin{array}{l}16.7 \\
18.4 \\
18.8 \\
19.2 \\
19.1\end{array}$ & $\begin{array}{l}1,706 \\
1,716 \\
1,753 \\
1,769 \\
1,760\end{array}$ \\
\hline \multicolumn{13}{|c|}{ Depletion period } \\
\hline $\begin{array}{rl}1 & \mathrm{D} \\
2 & \mathrm{D} \\
3 & \mathrm{D} \\
4 & \mathrm{D} \\
5 & \mathrm{D} \\
6 & \mathrm{D} \\
7 & \mathrm{D} \\
8 & \mathrm{D} \\
9 & \mathrm{D} \\
10 & \mathrm{D} \\
11 & \mathrm{D} \\
12 & \mathrm{D} \\
13 & \mathrm{D} \\
14 & \mathrm{D} \\
15 & \mathrm{D} \\
16 & \mathrm{D} \\
17 & \mathrm{D} \\
18 & \mathrm{D} \\
19 & \mathrm{D} \\
20 & \mathrm{D} \\
21 & \mathrm{D}\end{array}$ & $\begin{array}{l}2,710 \\
2,240 \\
2,680 \\
2,625 \\
2,420 \\
2,560 \\
2,550 \\
2,770 \\
2,730 \\
2,480 \\
2,940 \\
2,510 \\
2,435 \\
2,570 \\
2,825 \\
2,670 \\
2,860 \\
3,100 \\
2,850 \\
2,630 \\
2,570\end{array}$ & $\begin{array}{l}5.07 \\
5.30 \\
5.70 \\
5.85 \\
5.80 \\
5.98 \\
6.00 \\
6.03 \\
6.07 \\
6.15 \\
6.28 \\
6.22 \\
6.29 \\
6.27 \\
6.30 \\
6.30 \\
6.33 \\
6.42 \\
6.40 \\
6.45 \\
6.45\end{array}$ & $\begin{array}{l}1.008 \\
1.008 \\
1.007 \\
1.006 \\
1.007 \\
1.007 \\
1.007 \\
1.006 \\
1.006 \\
1.005 \\
1.006 \\
1.006 \\
1.007 \\
1.007 \\
1.006 \\
1.006 \\
1.006 \\
1.005 \\
1.006 \\
1.006 \\
1.007\end{array}$ & $\begin{array}{r}81 \\
53 \\
72 \\
70 \\
78 \\
84 \\
95 \\
102 \\
97 \\
88 \\
100 \\
95 \\
87 \\
85 \\
103 \\
80 \\
92 \\
104 \\
111 \\
81 \\
88\end{array}$ & $\begin{array}{c}39 \\
21 \\
18 \\
15 \\
13 \\
12 \\
9.8 \\
8.7 \\
8.4 \\
6.7 \\
6.6 \\
5.9 \\
5.1 \\
5.4 \\
4.7 \\
4.5 \\
4.5 \\
4.4 \\
4.4 \\
4.2 \\
4.2\end{array}$ & $\begin{array}{l}90 \\
96 \\
94 \\
90 \\
92 \\
96 \\
88 \\
93 \\
98 \\
94 \\
97 \\
93 \\
98 \\
94 \\
93 \\
89 \\
95 \\
95 \\
97 \\
92 \\
92\end{array}$ & $\begin{array}{l}54 \\
49 \\
38 \\
33 \\
35 \\
37 \\
33 \\
36 \\
34 \\
30 \\
27 \\
28 \\
28 \\
29 \\
29 \\
29 \\
27 \\
23 \\
26 \\
22 \\
23\end{array}$ & $\begin{array}{r}115 \\
78 \\
90 \\
89 \\
91 \\
112 \\
107 \\
109 \\
114 \\
107 \\
111 \\
109 \\
103 \\
99 \\
112 \\
96 \\
109 \\
117 \\
126 \\
94 \\
97\end{array}$ & $\begin{array}{l}47 \\
45 \\
44 \\
38 \\
39 \\
46 \\
42 \\
46 \\
44 \\
43 \\
43 \\
40 \\
44 \\
44 \\
47 \\
44 \\
44 \\
43 \\
46 \\
42 \\
43\end{array}$ & $\begin{array}{l}2.8 \\
2.3 \\
3.1 \\
3.3 \\
3.4 \\
4.5 \\
4.3 \\
4.7 \\
4.9 \\
4.6 \\
6.0 \\
5.5 \\
5.7 \\
6.4 \\
7.1 \\
6.0 \\
7.6 \\
9.3 \\
8.3 \\
7.7 \\
7.6\end{array}$ & $\begin{array}{l}18.6 \\
18.0 \\
17.7 \\
16.5 \\
16.5 \\
17.5 \\
16.3 \\
17.0 \\
16.8 \\
16.3 \\
16.6 \\
15.3 \\
15.6 \\
16.2 \\
16.8 \\
16.1 \\
16.7 \\
16.1 \\
16.7 \\
15.1 \\
15.8\end{array}$ & $\begin{array}{l}1,748 \\
1,741 \\
1,762 \\
1,752 \\
1,724 \\
1,713 \\
1,670 \\
1,745 \\
1,740 \\
1,736 \\
1,639 \\
1,807 \\
1,778 \\
1,773 \\
1,730 \\
1,675 \\
1,745 \\
1,682 \\
1,746 \\
1,710 \\
1,709\end{array}$ \\
\hline
\end{tabular}

* The daily average and the extremes of variation of the analyzed dietary components in the control period were: water, 3,800 ml.; $\mathrm{Na}$ (mean) 131, range, 129 to $133 \mathrm{mEq}$.; $\mathrm{K}, 108 \mathrm{mEq}$.; Cl, $232 \mathrm{mEq}$.; and $\mathrm{N}$ (mean) 16.9, range, 16.3 to $17.0 \mathrm{Gm}$. The figures for the depletion period were: water, 3,952, range 3,800 to $4,000 \mathrm{ml}$.; Na (mean) 124 , range, 114 to $130 \mathrm{mEq}$; $\mathrm{K}<1 \mathrm{mEq}$; $\mathrm{Cl}$, $125 \mathrm{mEq}$; ; and $\mathrm{N}$ (mean) 16.4 , range, 16.1 to $16.7 \mathrm{Gm}$. In Tables I through IV where the daily range of variation is not given for the mineral constituents, the content in the milk of the diet was too small for accurate analysis; therefore, the amount of the substance added to the diet was virtually the total amount ingested. Where no variation is given for the fluid volume, the daily intake was constant for that period. 
TABLE II

Metabolic data on Subject J. D. (normal $\mathrm{Na}^{+}$intake, $\mathrm{Cl}^{-}: \mathrm{HCO}_{3}^{-}=3: 1$ )-Intake* and urinary output of water, electrolytes, creatinine and nitrogen

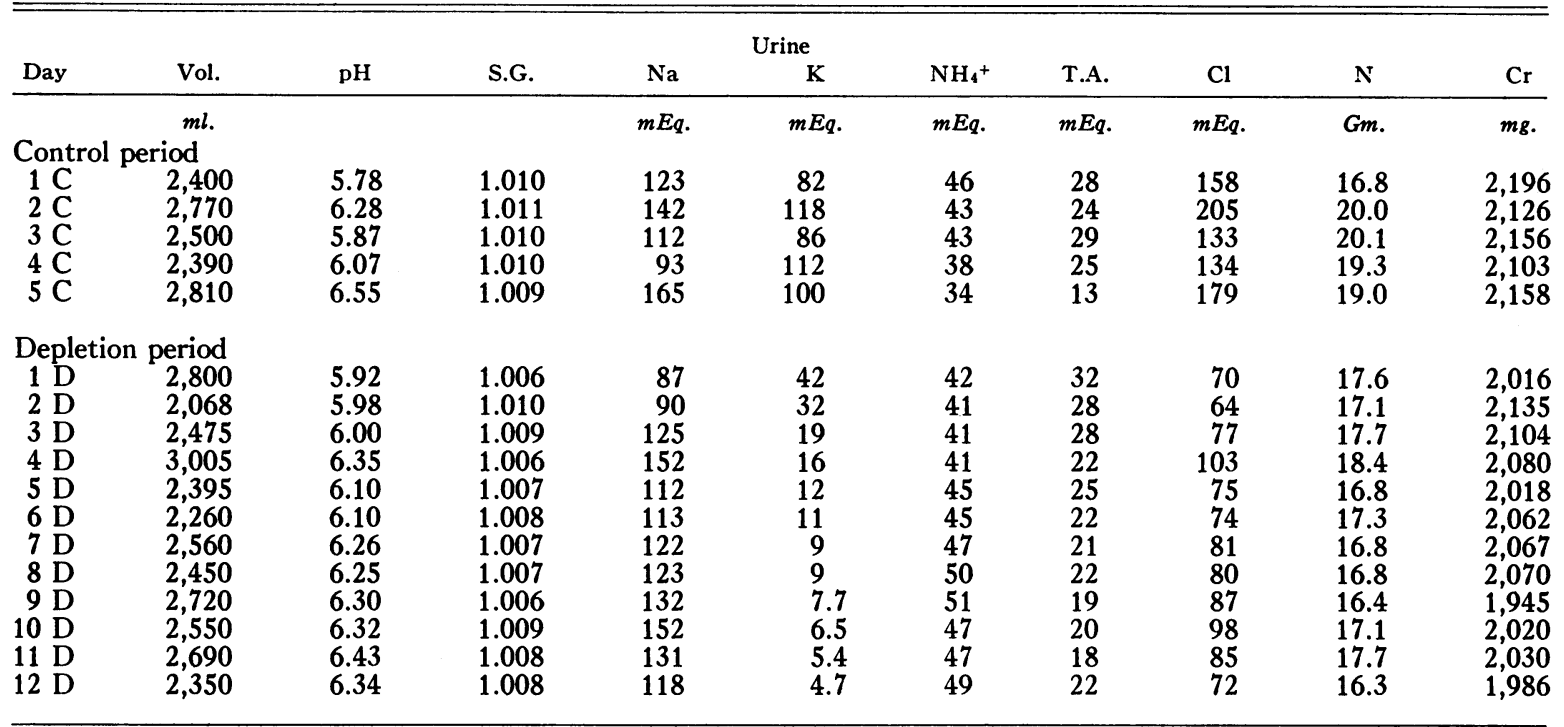

* The daily average and the extremes of variation of the analyzed dietary components in the control period were: water, 3,800 ml.; $\mathrm{Na}$ (mean) 128, range, 127 to $129 \mathrm{mEq}$.; $\mathrm{K}, 108 \mathrm{mEq}$.; Cl, $174 \mathrm{mEq}$. ; $\mathrm{HCO}_{3}, 58 \mathrm{mEq}$.; and $\mathrm{N}$ (mean) 16.9 , range, 16.9 to $17.0 \mathrm{Gm}$. The figures for the depletion period were: water, $3,800 \mathrm{ml}$.; $\mathrm{Na}(\operatorname{mean}) 130$, range, 129 to $132 \mathrm{mEq}$.; $\mathrm{K}<1 \mathrm{mEq}$.; $\mathrm{Cl}, 94 \mathrm{mEq}$. $\mathrm{HCO}_{3}, 31 \mathrm{mEq}$. ; and $\mathrm{N}$ (mean) 16.8, range, 16.3 to $17.4 \mathrm{Gm}$.

per day intake, C. P.2 and R. A. (Tables I and III), the nitrogen excretion decreased in relation to the nitrogen intake.
The excretion of creatinine showed no significant trend during the experiments.

The sum of the equivalents of titratable acid

TABLE III

Metabolic data on Subject $R$. A. (high $\mathrm{Na}^{+}$intake)-Intake* and urinary output of water, electrolytes, creatinine and nitrogen

\begin{tabular}{|c|c|c|c|c|c|c|c|c|c|c|}
\hline Day & Vol. & $\mathrm{pH}$ & S.G. & $\mathrm{Na}$ & ne & $\mathrm{NH}_{4}{ }^{+}$ & T.A. & $\mathrm{Cl}$ & $\mathbf{N}$ & $\mathrm{Cr}$ \\
\hline \multicolumn{11}{|c|}{ Control period } \\
\hline $\begin{array}{l}1 \mathrm{C} \\
2 \mathrm{C} \\
3 \\
4 \mathrm{C} \\
4 \mathrm{C} \\
5 \mathrm{C} \\
6 \mathrm{C}\end{array}$ & $\begin{array}{l}1,145 \\
1,990 \\
1,570 \\
1,735 \\
1,625 \\
1,315\end{array}$ & $\begin{array}{l}5.98 \\
5.40 \\
5.20 \\
5.15 \\
5.20 \\
5.22\end{array}$ & $\begin{array}{l}1.024 \\
1.015 \\
1.024 \\
1.021 \\
1.019 \\
1.024\end{array}$ & $\begin{array}{l}245 \\
306 \\
310 \\
343 \\
285 \\
265\end{array}$ & $\begin{array}{r}91 \\
104 \\
98 \\
116 \\
109 \\
99\end{array}$ & $\begin{array}{l}37 \\
54 \\
70 \\
73 \\
68 \\
76\end{array}$ & $\begin{array}{l}29 \\
31 \\
56 \\
55 \\
49 \\
51\end{array}$ & $\begin{array}{l}293 \\
406 \\
395 \\
450 \\
381 \\
368\end{array}$ & $\begin{array}{l}13.7 \\
15.4 \\
17.0 \\
18.2 \\
17.0 \\
17.5\end{array}$ & $\begin{array}{l}2,072 \\
1,945 \\
2,084 \\
2,104 \\
2,125 \\
2,035\end{array}$ \\
\hline \multicolumn{11}{|c|}{ Depletion period } \\
\hline $\begin{array}{ll}1 & \mathrm{D} \\
2 & \mathrm{D} \\
3 & \mathrm{D} \\
4 & \mathrm{D} \\
5 & \mathrm{D} \\
6 & \mathrm{D} \\
7 & \mathrm{D} \\
8 & \mathrm{D}\end{array}$ & $\begin{array}{l}1,420 \\
1,875 \\
1,615 \\
1,645 \\
1,940 \\
1,360 \\
2,205 \\
1,525\end{array}$ & $\begin{array}{l}\mathbf{5 . 4 0} \\
\mathbf{5 . 5 5} \\
\mathbf{5 . 6 2} \\
\mathbf{5 . 6 1} \\
\mathbf{5 . 6 3} \\
\mathbf{5 . 9 0} \\
\mathbf{6 . 2 1} \\
\mathbf{6 . 0 3}\end{array}$ & $\begin{array}{l}1.019 \\
1.019 \\
1.015 \\
1.013 \\
1.023 \\
1.021 \\
1,012 \\
1.014\end{array}$ & $\begin{array}{l}224 \\
235 \\
235 \\
233 \\
191 \\
268 \\
321 \\
232\end{array}$ & $\begin{array}{l}63 \\
38 \\
28 \\
20 \\
17 \\
17 \\
11 \\
12\end{array}$ & $\begin{array}{l}71 \\
74 \\
80 \\
65 \\
61 \\
74 \\
60 \\
61\end{array}$ & $\begin{array}{l}47 \\
47 \\
44 \\
31 \\
33 \\
38 \\
25 \\
28\end{array}$ & $\begin{array}{l}291 \\
269 \\
258 \\
255 \\
203 \\
274 \\
339 \\
236\end{array}$ & $\begin{array}{l}15.5 \\
16.1 \\
17.5 \\
14.1 \\
13.6 \\
16.1 \\
13.0 \\
12.9\end{array}$ & $\begin{array}{l}1,860 \\
1,973 \\
2,249 \\
1,968 \\
1,828 \\
2,360 \\
1,725 \\
1,731\end{array}$ \\
\hline
\end{tabular}

* The daily average and the extremes of variation of the analyzed dietary components in the control period were: water (mean) 4,057, range, 3,840 to $4,250 \mathrm{ml}$; $\mathrm{Na}$ (mean) 348 , range, 347 to $349 \mathrm{mEq}$.; $\mathrm{K}, 110 \mathrm{mEq}$.; $\mathrm{Cl}, 454 \mathrm{mEq}$.; and $\mathrm{Na}$ (mean) 16.9 , range, 16.5 to $16.9 \mathrm{Gm}$. The figures for the depletion period were: water (mean) 3,875 , range, 3,800 to $4,050 \mathrm{ml}$.; $\mathrm{Na}$ (mean) 348 , range, 347 to $349 \mathrm{mEq} . ; \mathrm{K}<1 \mathrm{mEq}$; $\mathrm{Cl}, 345 \mathrm{mEq} . ;$ and $\mathrm{N}$ (mean) 16.3 , range, 16.3 to $16.9 \mathrm{Gm}$ 
and ammonium ion excreted by the kidney per 24 hours depended upon whether the subject had a portion of the total cations ingested with bicarbonate ions or almost entirely with chloride ions. In Subjects C. P.2 and R. A., where the total cations ingested were associated almost entirely with chloride ions, the excretion of titratable acid plus ammonium ions was increased during the control periods and decreased during the potassium depletion periods (Tables I and III, Figure 3). In Subjects J. D. and J. B., where the total cations ingested were associated with bicarbonate and chloride ions in a ratio of $1: 3$, there was no consistent change in titratable acidity plus ammonium ion excretion during either the control or depletion periods (Tables II and IV, Figure 3). Both the titratable acid and ammonia increased in the urine during the control periods when bicarbonate was not added to the diet, Subjects
C. P.2 and R.A. (Figure 3). But in all four subjects the daily excretion of titratable acid decreased and urinary $\mathrm{pH}$ rose in the depletion period.

The urinary carbon dioxide and bicarbonate increased during the potassium depletion in Subject C. P.2 (Table I).

\section{Fecal excretion}

These data from the subjects ingesting less than $1 \mathrm{mEq}$. potassium per day are presented in Table V.

The percentage of stool solids per stool collection period remained fairly constant for each individual except one (J. B.); there was, however, a wide variation in solids among the various subjects (8 to 34 per cent). The grams of nitrogen per $100 \mathrm{Gm}$. stool solids increased in three of these subjects and decreased in one. The amount

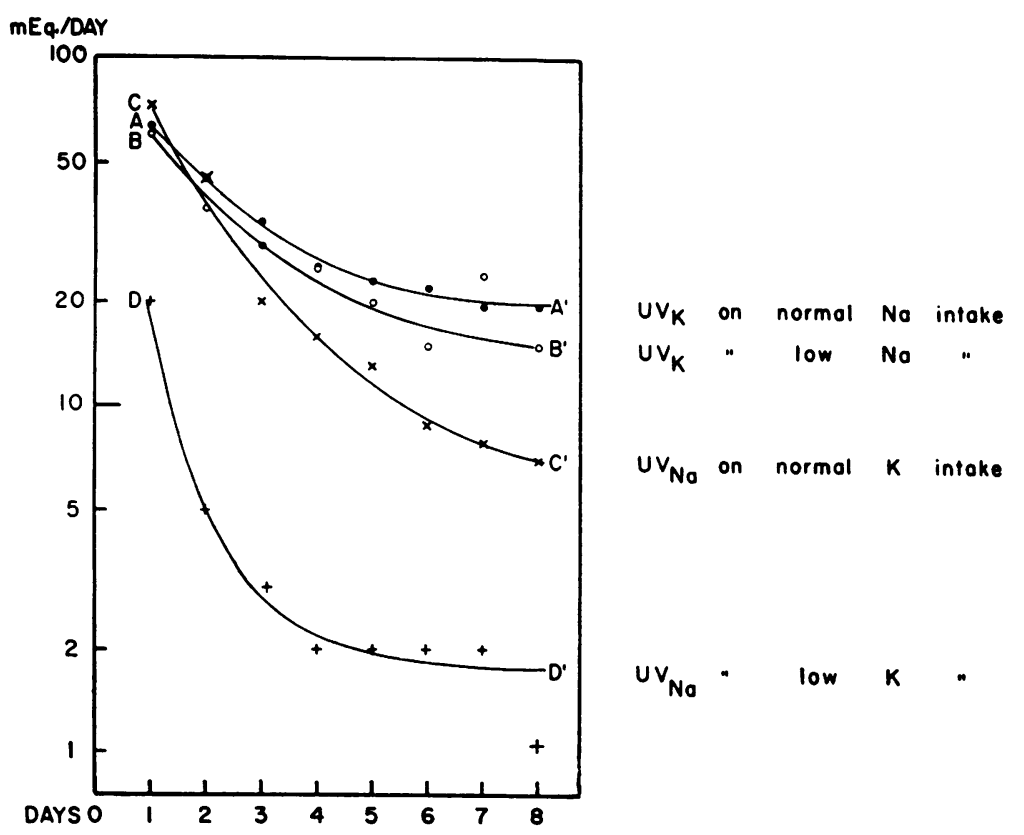

Fig. 2. The Renal Conservation of Potassium and Sodium

The excretion rates of potassium are plotted against time for two subjects receiving $14 \mathrm{mEq}$. per day of potassium; one, E. H.2, with a normal intake of sodium of $130 \mathrm{mEq}$. per day (curve $\mathrm{A}-\mathrm{A}^{1}$ ) and one, R. S.2, with a low intake of sodium of $14 \mathrm{mEq}$. per day (curve $\mathrm{B}-\mathrm{B}^{1}$ ).

The excretion rates of sodium are plotted against time for two subjects receiving $14 \mathrm{mEq}$. per day of sodium; one, E. W.2, with a normal intake of potassium of 90 $\mathrm{mEq}$. per day (curve C-C) and one, R. S.2, with a low intake of potassium of 14 mEq. per day (curve $D^{-} D^{1}$ ).

This graph indicates that the rate of decline of urinary sodium was clearly more rapid than that of potassium under comparable reduction of intake of the respective ions. Sodium excretions were comparable on Day 0. 


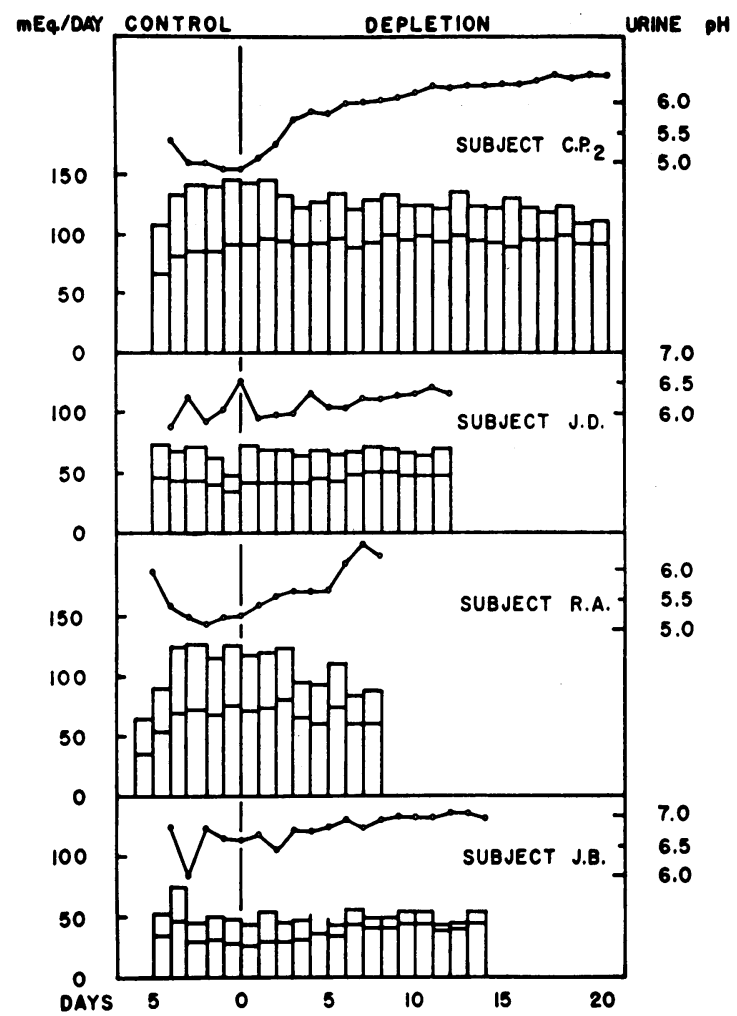

Fig. 3. The Daily Excretion of Ammonium Ion Plus Titratable Acidity and the Daily Urine PH

Ammonium ion excretion is indicated by the lower portions and the titratable acid by the upper portions of the bars. The dots indicate the $\mathrm{pH}$ of the total 24 hour urine volume. Subjects C. P.2 and J. D. received normal intakes of sodium (130 mEq. per day); Subjects R. A. and $\mathrm{J}$. B. received high sodium intakes $(340 \mathrm{mEq}$. per day) Subjects C. P.2 and R. A. ingested only chloride as the supplemental anion and Subjects J. D. and J. B. received bicarbonate and chloride in a ratio of $1: 3$ as the supplemental anions.

Urinary $\mathrm{pH}$ rose and titratable acidity decreased during the depletion period in all subjects; excretion of ammonium ion was either unchanged or increased.

of potassium per unit stool solids (mEq. per 100 $\mathrm{Gm}$.) decreased in every subject; nevertheless, the fecal loss of this ion accounted for from 11 to 59 per cent of the total loss in these subjects on the very low intake of potassium (Table VI). The amount of sodium per unit stool solids was increased in three of the four subjects and was unchanged in the other; this increase in stool sodium was not related to an increase in oral intake of the ion. There was no remarkable or consistent change in the fecal chloride excretion among the various subjects.

\section{Total balances of electrolytes and nitrogen}

These data are presented in Table VII.

1. Potassium. On normal intakes of sodium during the depletion period the negative balance of potassium tended to become greater the lower the level of potassium intake. When compared at the end of seven days of potassium depletion, Subject C. P. ${ }_{1}$ lost 66 and Subject T. C. $165 \mathrm{mEq}$. of potassium while ingesting between 25 and 30 mEq. potassium per day; Subject E. H. ingesting approximately $14 \mathrm{mEq}$. of potassium per day lost 235 and $189 \mathrm{mEq}$. potassium during two separate studies; and at the lowest level of intake, less than $1 \mathrm{mEq}$. potassium per day, Subject C. P. 2 lost 260 and Subject J. D. lost $192 \mathrm{mEq}$. of potassium. The largest negative potassium balance, $-502 \mathrm{mEq}$., was in one of the subjects in the last group, C. $P_{.2}$, who was maintained on less than $1 \mathrm{mEq}$. per day for three weeks. For the entire 26 days of the study in this patient the total potassium balance was $-6.5 \mathrm{mEq}$. per $\mathrm{Kg}$. of body weight; the balance of potassium "in excess of nitrogen" was $-4.5 \mathrm{mEq}$. per $\mathrm{Kg}$.

High intake of potassium in the control period led to a greater loss during the depletion period in both Subjects D. S. and L. P., but resulted in a greater final depletion only in L. P. since in D. S. potassium was retained initially in the control period.

2. Sodium. The sodium balances were positive consistently during the depletion periods except when the sodium intake was restricted to $14 \mathrm{mEq}$. per day.

3. Chloride. The chloride balance tended to be positive when the balance of sodium was strongly positive. The balance of chloride was most accurately determined in the subjects on the diet of resin-treated milk containing less than $1 \mathrm{mEq}$. per day of $\mathrm{K}$. This was due to the fact that the resin treatment removed virtually all of the chloride: The amount of chloride put in the milk diet could be more accurately measured than that in the natural foodstuffs.

4. Nitrogen. Urinary nitrogen excretion for the most part reflected the nitrogen intake; however, in Subjects C. P. and R. A. (Tables I and III, respectively) the $U V_{N}$ appeared to decline somewhat. This observation could not be accounted for by a decrease in nitrogen intake. 
TABLE IV

Metabolic data on Subject J. B. (high $\mathrm{Na}^{+}$intake, $\mathrm{Cl}^{-}: \mathrm{HCO}_{3}^{-}=3: 1$ )-Intake* and urinary output of water, electrolytes, creatinine and nitrogen

\begin{tabular}{|c|c|c|c|c|c|c|c|c|c|c|}
\hline Day & Vol. & $\mathrm{pH}$ & S.G. & $\mathrm{Na}$ & $\begin{array}{l}\text { Urine } \\
\qquad \mathbf{K}\end{array}$ & $\mathrm{NH}_{4}{ }^{+}$ & T.A. & $\mathrm{Cl}$ & $\mathbf{N}$ & $\mathrm{Cr}$ \\
\hline \multicolumn{11}{|c|}{ Control period } \\
\hline $\begin{array}{l}1 \mathrm{C} \\
2 \mathrm{C} \\
3 \mathrm{C} \\
4 \mathrm{C} \\
5 \mathrm{C}\end{array}$ & $\begin{array}{l}3,850 \\
1,420 \\
2,840 \\
2,610 \\
2,600\end{array}$ & $\begin{array}{l}6.80 \\
5.98 \\
6.78 \\
6.60 \\
6.58\end{array}$ & $\begin{array}{l}1.007 \\
1.018 \\
1.012 \\
1.012 \\
1.013\end{array}$ & $\begin{array}{l}263 \\
233 \\
355 \\
326 \\
365\end{array}$ & $\begin{array}{r}77 \\
44 \\
95 \\
75 \\
121\end{array}$ & $\begin{array}{l}35 \\
47 \\
30 \\
31 \\
28\end{array}$ & $\begin{array}{l}16 \\
29 \\
16 \\
19 \\
20\end{array}$ & $\begin{array}{l}263 \\
231 \\
337 \\
298 \\
360\end{array}$ & $\begin{array}{l}15.6 \\
15.6 \\
18.6 \\
16.5 \\
17.0\end{array}$ & $\begin{array}{l}1,940 \\
2,130 \\
2,002 \\
2,010 \\
2,048\end{array}$ \\
\hline \multicolumn{11}{|c|}{ Depletion period } \\
\hline $\begin{array}{rl}1 & \mathrm{D} \\
2 & \mathrm{D} \\
3 & \mathrm{D} \\
4 & \mathrm{D} \\
5 & \mathrm{D} \\
6 & \mathrm{D} \\
7 & \mathrm{D} \\
8 & \mathrm{D} \\
9 & \mathrm{D} \\
10 & \mathrm{D} \\
11 & \mathrm{D} \\
12 & \mathrm{D} \\
13 & \mathrm{D} \\
14 & \mathrm{D}\end{array}$ & $\begin{array}{l}2,680 \\
2,060 \\
2,440 \\
2,600 \\
2,590 \\
2,500 \\
2,210 \\
2,580 \\
2,740 \\
2,630 \\
2,560 \\
2,370 \\
2,520 \\
2,760\end{array}$ & $\begin{array}{l}6.68 \\
6.42 \\
6.75 \\
6.72 \\
6.80 \\
6.92 \\
6.80 \\
6.90 \\
6.97 \\
6.96 \\
6.97 \\
7.07 \\
7.06 \\
6.94\end{array}$ & $\begin{array}{l}1.011 \\
1.011 \\
1.012 \\
1.011 \\
1.010 \\
1.010 \\
1.012 \\
1.009 \\
1.009 \\
1.009 \\
1.009 \\
1.009 \\
1.009 \\
1.009\end{array}$ & $\begin{array}{l}252 \\
231 \\
264 \\
305 \\
303 \\
300 \\
272 \\
323 \\
305 \\
322 \\
252 \\
307 \\
301 \\
360\end{array}$ & $\begin{array}{c}70 \\
36 \\
26 \\
19 \\
11 \\
16 \\
7.8 \\
9.3 \\
8.0 \\
8.9 \\
7.4 \\
9.7 \\
5.0 \\
5.8\end{array}$ & $\begin{array}{l}26 \\
30 \\
29 \\
31 \\
36 \\
34 \\
43 \\
41 \\
41 \\
44 \\
44 \\
38 \\
39 \\
45\end{array}$ & $\begin{array}{r}17 \\
24 \\
16 \\
16 \\
\\
9 \\
13 \\
9 \\
9 \\
10 \\
9 \\
5 \\
5 \\
9\end{array}$ & $\begin{array}{l}216 \\
170 \\
183 \\
233 \\
220 \\
233 \\
199 \\
246 \\
231 \\
247 \\
194 \\
229 \\
209 \\
277\end{array}$ & $\begin{array}{l}16.5 \\
16.9 \\
17.5 \\
16.8 \\
17.2 \\
14.9 \\
17.0 \\
16.1 \\
16.6 \\
17.5 \\
16.2 \\
14.9 \\
16.4 \\
16.1\end{array}$ & $\begin{array}{l}1,896 \\
1,921 \\
2,007 \\
1,970 \\
2,040 \\
1,781 \\
2,127 \\
1,980 \\
1,939 \\
2,157 \\
1,984 \\
2,015 \\
1,909 \\
1,980\end{array}$ \\
\hline
\end{tabular}

* The daily average and the extremes of variation of the analyzed dietary components for the control period were: fluid volume (mean) 3,837, range, 3,699 to $4,000 \mathrm{ml}$. ; $\mathrm{Na}$ (mean) 312 , range, 168 to $348 \mathrm{mEq}$. ( $\mathrm{Na}^{+}$intake increased stepwise during control period) ; $\mathrm{K}$ (mean) 98 , range, 55 to $109 \mathrm{mEq}$. ( $\mathrm{K}^{+}$intake too low on the first day due to dietary error) ; $\mathrm{Cl}$ (mean) 303, range, 161 to $339 \mathrm{mEq}$; $\mathrm{HCO}_{3}$ (mean) 101, range, 54 to $113 \mathrm{mEq}$; and $\mathrm{N}$ (mean) 16.8, range, 16.3 to $17.2 \mathrm{Gm}$. The figures for the depletion period were: fluid volume $3,800 \mathrm{ml}$.; $\mathrm{Na}$ (mean) 348 , range, 347 to 349 mEq.; $\mathrm{K}<1 \mathrm{mEq}$.; $\mathrm{Cl}, 259 \mathrm{mEq} . ; \mathrm{HCO}_{3}, 86 \mathrm{mEq}$.; and $\mathrm{N}$ (mean) 16.5 , range, 15.6 to $17.3 \mathrm{Gm}$.

\section{Concentrations of electrolytes in serum}

The concentration of potassium in serum fell progressively during the depletion period in all experiments, reaching the lowest value of 2.8 $\mathrm{mEq}$. per L. in the subject on the lowest intake of $\mathrm{K}$ for the longest period, C. $\mathrm{P}_{2}$ (Table VIII). There were no apparent trends in the daily serum concentrations of sodium, chloride or creatinine. The venous $\mathrm{CO}_{2}$ content rose slightly in Subjects C. $P_{.2}$ and $R$. A. but remained within normal limits.

\section{Acid-base changes in "arterialized" finger capillary blood}

Periodic samples of "arterialized" finger capillary blood showed no major changes in the whole blood $\mathrm{pH}, \mathrm{CO}_{2}$ content or "buffer base" (Table VIII).

\section{DISCUSSION}

Our data indicate that subjects ingesting an adequate diet containing at least $25 \mathrm{mEq}$. of potassium per day are unlikely to develop potassium depletion greater than $250 \mathrm{mEq}$. as the result of urinary potassium loss alone. This is probably also true for intakes of $14 \mathrm{mEq}$. per day. At both levels of intake the urinary potassium daily loss had reached or almost reached the intake levels within the duration of these studies (Figure 1). At the extremely low intake of $1 \mathrm{mEq}$. per day, however, the decline in the urinary loss was very slow in the last five days of a 21 day study (C. P.2) as shown in Figure 4. Therefore, under the circumstance of prolonged and practically complete deprivation of potassium, the urinary loss, while not more than about $3 \mathrm{mEq}$. above the intake, could reasonably be expected to continue to add significantly to the deficit of the ion.

In the first day of depletion, however, the drop in potassium intake is a more significant factor in determining the contribution of the urinary potassium loss to the depletion. Those subjects loaded with potassium during the control period, 
TABLE V

Analysis of average daily stool values

\begin{tabular}{|c|c|c|c|c|c|c|c|c|c|}
\hline \multirow[b]{2}{*}{ Subject } & \multicolumn{2}{|c|}{ Stool collection } & \multirow{2}{*}{$\begin{array}{c}\text { Total } \\
\text { weight }\end{array}$} & \multirow{2}{*}{$\begin{array}{l}\text { Total } \\
\text { solids }\end{array}$} & \multirow[b]{2}{*}{$\mathrm{Na}$} & \multirow[b]{2}{*}{ K } & \multirow[b]{2}{*}{$\mathrm{Cl}$} & \multirow[b]{2}{*}{$\mathbf{N}$} & \multirow{2}{*}{$\underset{\text { ratio }}{\mathrm{K} / \mathrm{Na}}$} \\
\hline & Period & Duration & & & & & & & \\
\hline \multirow[t]{4}{*}{ C. P.2 } & Control & $\begin{array}{l}\text { days } \\
\text { eriod }\end{array}$ & Gm. & $\mathrm{Gm}$. & $m E q$. & $m E q$. & $m E q$. & $\mathrm{Gm}$. & \\
\hline & II & $\begin{array}{l}2 \\
3\end{array}$ & $\begin{array}{l}525 \\
175\end{array}$ & $\begin{array}{l}71.0 \\
30.1\end{array}$ & $\begin{array}{r}13.2 \\
2.6\end{array}$ & $\begin{array}{l}40.3 \\
22.2\end{array}$ & $\begin{array}{l}4.9 \\
1.8\end{array}$ & $\begin{array}{l}3.6 \\
1.4\end{array}$ & $\begin{array}{l}3.1 \\
8.5\end{array}$ \\
\hline & Depletic & period & & & & & & & \\
\hline & $\begin{array}{r}\text { I } \\
\text { II } \\
\text { III } \\
\text { IV } \\
\text { V } \\
\text { VI } \\
\text { VII }\end{array}$ & $\begin{array}{l}3 \\
3 \\
3 \\
3 \\
3 \\
3 \\
3\end{array}$ & $\begin{array}{l}193 \\
155 \\
207 \\
173 \\
168 \\
174 \\
164\end{array}$ & $\begin{array}{l}36.5 \\
27.6 \\
38.3 \\
30.2 \\
31.4 \\
29.8 \\
31.9\end{array}$ & $\begin{array}{r}4.3 \\
7.2 \\
13.4 \\
9.0 \\
7.8 \\
8.0 \\
7.6\end{array}$ & $\begin{array}{r}24.9 \\
15.9 \\
16.3 \\
14.1 \\
12.0 \\
9.5 \\
11.4\end{array}$ & $\begin{array}{l}1.8 \\
1.5 \\
2.1 \\
1.5 \\
1.4 \\
1.2 \\
1.0\end{array}$ & $\begin{array}{l}1.6 \\
1.8 \\
1.8 \\
1.6 \\
1.6 \\
1.5 \\
1.7\end{array}$ & $\begin{array}{l}5.8 \\
2.2 \\
1.2 \\
1.6 \\
1.5 \\
1.2 \\
1.5\end{array}$ \\
\hline \multirow[t]{4}{*}{ J. D. } & Control & eriod & & & & & & & \\
\hline & II & $\begin{array}{l}2 \\
3\end{array}$ & $\begin{array}{r}103 \\
77\end{array}$ & $\begin{array}{l}31 \\
22\end{array}$ & $\begin{array}{l}0.9 \\
0.7\end{array}$ & $\begin{array}{l}15.5 \\
12.5\end{array}$ & $\begin{array}{l}0.5 \\
0.3\end{array}$ & $\begin{array}{l}1.05 \\
0.70\end{array}$ & $\begin{array}{l}17.2 \\
17.9\end{array}$ \\
\hline & Depletic & period & & & & & & & \\
\hline & $\begin{array}{r}\text { I } \\
\text { II } \\
\text { III }\end{array}$ & $\begin{array}{l}3 \\
3 \\
3\end{array}$ & $\begin{array}{l}52 \\
66 \\
60\end{array}$ & $\begin{array}{l}16 \\
21 \\
18\end{array}$ & $\begin{array}{l}1.1 \\
3.0 \\
4.0\end{array}$ & $\begin{array}{l}8.1 \\
9.2 \\
5.7\end{array}$ & $\begin{array}{l}0.3 \\
0.3 \\
0.5\end{array}$ & $\begin{array}{l}0.49 \\
0.63 \\
0.59\end{array}$ & $\begin{array}{l}7.4 \\
3.1 \\
1.4\end{array}$ \\
\hline \multirow[t]{4}{*}{ R. A } & Control & eriod & & & & & & & \\
\hline & II & $\begin{array}{l}4 \\
2\end{array}$ & $\begin{array}{l}106 \\
110\end{array}$ & $\begin{array}{l}8.2 \\
8.8\end{array}$ & $\begin{array}{l}7.0 \\
4.5\end{array}$ & $\begin{array}{r}8.8 \\
14.0\end{array}$ & $\begin{array}{l}2.5 \\
5.0\end{array}$ & $\begin{array}{l}1.15 \\
1.10\end{array}$ & $\begin{array}{l}1.26 \\
3.11\end{array}$ \\
\hline & Depleti & period & & & & & & & \\
\hline & II & $\begin{array}{l}6 \\
2\end{array}$ & $\begin{array}{l}53 \\
52\end{array}$ & $\begin{array}{l}5.0 \\
3.6\end{array}$ & $\begin{array}{l}2.5 \\
2.5\end{array}$ & $\begin{array}{l}3.3 \\
2.5\end{array}$ & $\begin{array}{l}0.2 \\
0.5\end{array}$ & $\begin{array}{l}0.80 \\
0.70\end{array}$ & $\begin{array}{l}1.32 \\
1.00\end{array}$ \\
\hline \multirow[t]{4}{*}{ J. B. } & Control & beriod & & & & & & & \\
\hline & II & $\begin{array}{l}2 \\
3\end{array}$ & $\begin{array}{r}117 \\
68\end{array}$ & $\begin{array}{l}17 \\
29\end{array}$ & $\begin{array}{l}2.5 \\
1.7\end{array}$ & $\begin{array}{r}18.2 \\
7.8\end{array}$ & $\begin{array}{l}1.4 \\
0.6\end{array}$ & $\begin{array}{l}0.80 \\
0.38\end{array}$ & $\begin{array}{l}7.3 \\
4.6\end{array}$ \\
\hline & Depleti & period & & & & & & & \\
\hline & $\begin{array}{r}\text { I } \\
\text { II } \\
\text { III } \\
\text { IV } \\
\text { V }\end{array}$ & $\begin{array}{l}3 \\
3 \\
2 \\
2 \\
4\end{array}$ & $\begin{array}{l}72 \\
40 \\
79 \\
44 \\
39\end{array}$ & $\begin{array}{l}26 \\
13 \\
26 \\
17 \\
12\end{array}$ & $\begin{array}{l}4.7 \\
2.8 \\
7.4 \\
4.7 \\
3.1\end{array}$ & $\begin{array}{l}8.6 \\
4.0 \\
5.8 \\
3.8 \\
2.6\end{array}$ & $\begin{array}{l}0.6 \\
4.0 \\
5.8 \\
3.8 \\
3.8\end{array}$ & $\begin{array}{l}0.60 \\
0.35 \\
0.75 \\
0.55 \\
0.50\end{array}$ & $\begin{array}{l}1.8 \\
1.4 \\
0.78 \\
0.81 \\
0.84\end{array}$ \\
\hline
\end{tabular}

D. S. and L. P., lost, respectively, 129 and 127 other subjects on a comparable depletion intake $\mathrm{mEq}$. in the urine on the first depletion day as (25 mEq. per day). However, despite the greater contrasted with losses of 29 to $52 \mathrm{mEq}$. in the urinary loss on the first day in these subjects

TABLE VI

Per cent of total potassium loss and per cent solids in stools during potassium depletion period

\begin{tabular}{|c|c|c|c|c|c|c|}
\hline Subject & $\begin{array}{l}\text { Period } \\
\text { duration }\end{array}$ & $\underset{\mathbf{K}}{\text { Urine }}$ & $\underset{\mathbf{K}}{\text { Stool }}$ & $\begin{array}{l}\text { Total } \\
\text { K loss }\end{array}$ & $\begin{array}{c}\mathrm{K} \text { loss in } \\
\text { stool }\end{array}$ & $\begin{array}{l}\text { Stool } \\
\text { solids }\end{array}$ \\
\hline \multirow{3}{*}{$\begin{array}{l}\text { Normal sodium intake } \\
\text { C. P.2 } \\
\text { J. D. } \\
\text { High sodium intake } \\
\text { R. A. } \\
\text { J. B. }\end{array}$} & days & $m E q$ & $m E q$ & $m E q$ & $\%$ & $\%$ \\
\hline & $\begin{array}{l}21 \\
12\end{array}$ & $\begin{array}{l}216 \\
174\end{array}$ & $\begin{array}{r}307 \\
86\end{array}$ & $\begin{array}{l}523 \\
260\end{array}$ & $\begin{array}{l}59 \\
33\end{array}$ & $\begin{array}{l}19 \\
31\end{array}$ \\
\hline & $\begin{array}{r}8 \\
14\end{array}$ & $\begin{array}{l}206 \\
270\end{array}$ & $\begin{array}{l}25 \\
67\end{array}$ & $\begin{array}{l}231 \\
307\end{array}$ & $\begin{array}{l}11 \\
22\end{array}$ & $\begin{array}{r}8 \\
34\end{array}$ \\
\hline
\end{tabular}


RENAL CONSERVATION IN EXPERIMENTAL POTASSIUM DEPLETION

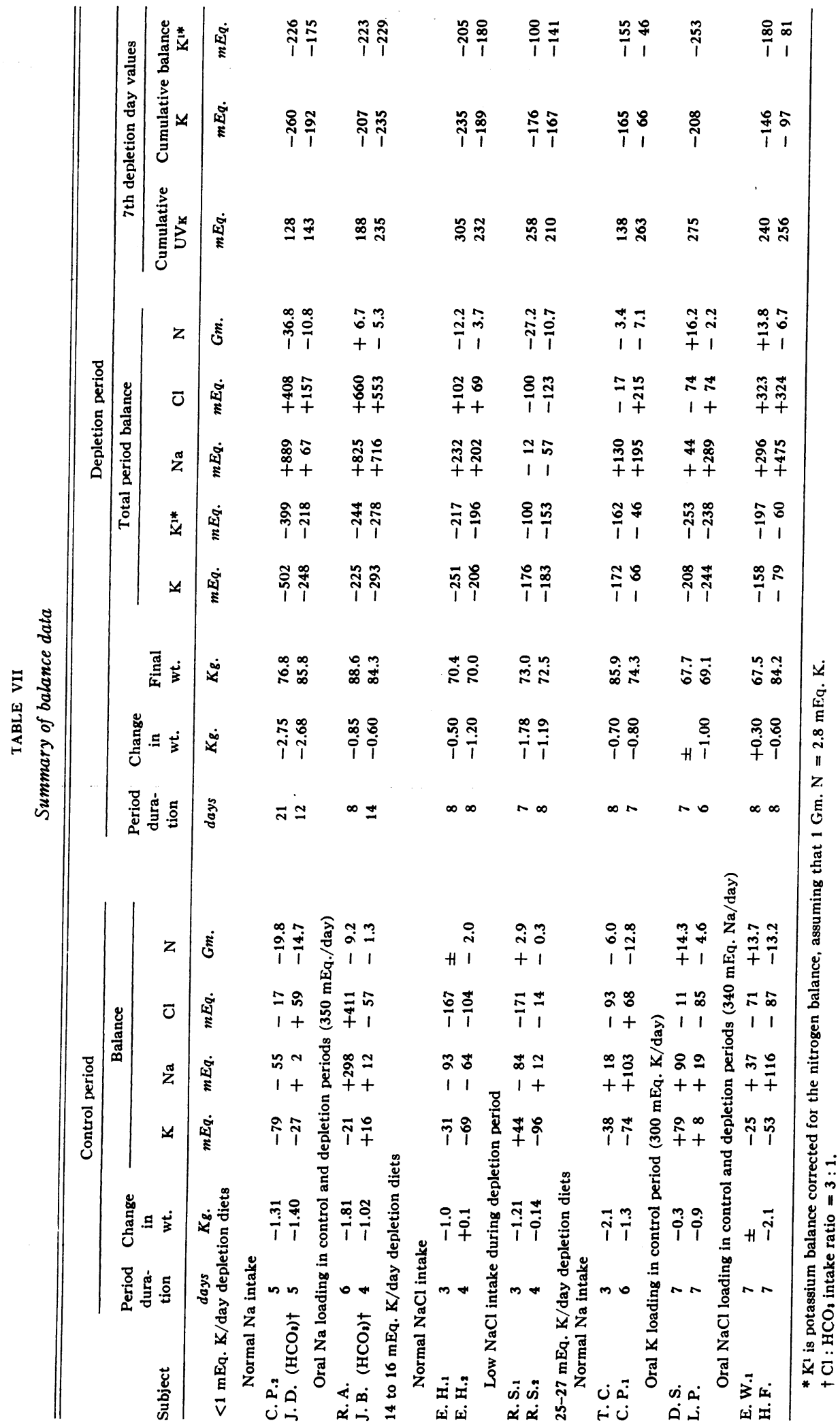


TABLE VIII

Analysis of blood and serum

\begin{tabular}{|c|c|c|c|c|c|c|c|c|c|c|c|c|}
\hline \multirow[b]{2}{*}{ Subject } & \multirow[b]{2}{*}{ Day } & \multicolumn{6}{|c|}{ Whole blood* } & \multicolumn{5}{|c|}{ Venous serum } \\
\hline & & $\mathrm{pH}$ & $\mathrm{CO}_{2}$ & $\mathrm{pCO}_{2}$ & $\mathbf{B b}$ & Cell vol. & $\mathrm{Hb}$ & $\mathrm{Na}$ & $\mathbf{K}$ & $\mathrm{Cl}$ & $\mathrm{CO}_{2}$ & Creatinine \\
\hline \multirow[t]{2}{*}{ C. $P_{.2}$} & C 5 & 7.39 & $\begin{array}{c}\text { mMoles } / L . \\
21.7\end{array}$ & $\begin{array}{c}m m . \mathrm{Hg} \\
42.0\end{array}$ & $\begin{array}{c}m E q . / L \\
48.5\end{array}$ & $\begin{array}{c}\% \\
46.5\end{array}$ & $\begin{array}{c}\text { mMoles } / L \\
9.20\end{array}$ & $\begin{array}{c}m E q . / L . \\
140\end{array}$ & $\begin{array}{c}m E q . / L . \\
4.1\end{array}$ & $\begin{array}{c}m E q . / L . \\
104\end{array}$ & $\begin{array}{c}m \text { Moles } / L \\
26.1\end{array}$ & $\begin{array}{c}m g . \% \\
1.10\end{array}$ \\
\hline & $\begin{array}{lr}\text { D } & 7 \\
\text { D } & 12 \\
\text { D } & 14 \\
D & 16 \\
\text { D } & 19 \\
\text { D } & 21\end{array}$ & $\begin{array}{r}7.41 \\
7.42 \\
7.44 \\
-7.41 \\
7.43 \\
7.43\end{array}$ & $\begin{array}{l}20.5 \\
20.6 \\
21.5 \\
21.1 \\
21.1 \\
21.1\end{array}$ & $\begin{array}{l}38.0 \\
38.0 \\
38.0 \\
39.0 \\
38.0 \\
38.0\end{array}$ & $\begin{array}{l}48.0 \\
48.0 \\
49.5 \\
48.0 \\
48.5 \\
49.0\end{array}$ & $\begin{array}{l}46.5 \\
44.0 \\
44.5 \\
43.0 \\
43.5 \\
44.0\end{array}$ & $\begin{array}{l}9.15 \\
9.00 \\
9.00 \\
8.65 \\
8.85 \\
8.95\end{array}$ & $\begin{array}{l}140 \\
140 \\
140 \\
140 \\
140 \\
141\end{array}$ & $\begin{array}{l}3.5 \\
3.3 \\
3.1 \\
3.1 \\
2.8 \\
2.8\end{array}$ & $\begin{array}{l}104 \\
104 \\
106 \\
104 \\
104 \\
107\end{array}$ & $\begin{array}{l}26.9 \\
28.0 \\
28.6 \\
30.6 \\
29.8 \\
29.6\end{array}$ & $\begin{array}{l}0.93 \\
1.20 \\
1.60 \\
1.10 \\
1.40 \\
0.90\end{array}$ \\
\hline \multirow[t]{2}{*}{ J. D. } & C 5 & 7.44 & 21.3 & 38.0 & 50.0 & 47.0 & 9.55 & 140 & 4.0 & 104 & 29.3 & 1.10 \\
\hline & $\begin{array}{l}\text { D } 6 \\
\text { D } 12\end{array}$ & $\begin{array}{l}7.42 \\
7.40\end{array}$ & $\begin{array}{l}21.0 \\
21.0\end{array}$ & $\begin{array}{l}38.0 \\
40.5\end{array}$ & $\begin{array}{l}48.5 \\
48.5\end{array}$ & $\begin{array}{l}45.5 \\
48.0\end{array}$ & $\begin{array}{l}9.25 \\
9.60\end{array}$ & $\begin{array}{l}140 \\
140\end{array}$ & $\begin{array}{l}3.9 \\
3.7\end{array}$ & $\begin{array}{l}102 \\
103\end{array}$ & $\begin{array}{l}28.8 \\
29.8\end{array}$ & $\begin{array}{l}0.93 \\
0.85\end{array}$ \\
\hline \multirow[t]{2}{*}{ R. A. } & C 3 & 7.38 & 18.4 & 37.0 & 45.5 & 47.0 & & 138 & 4.0 & 105 & 23.1 & 1.20 \\
\hline & D 8 & 7.45 & 19.8 & 34.0 & 48.0 & 45.0 & & 143 & 3.0 & 104 & 30.1 & 0.92 \\
\hline \multirow[t]{2}{*}{ J. B. } & C 5 & 7.44 & 22.1 & 38.5 & 50.0 & 43.0 & 8.65 & 139 & 4.2 & 105 & 31.2 & 0.90 \\
\hline & $\begin{array}{lr}\text { D } & 4 \\
\text { D } & 8 \\
\text { D } & 14\end{array}$ & $\begin{array}{l}7.45 \\
7.43 \\
7.43\end{array}$ & $\begin{array}{l}21.3 \\
20.9 \\
21.8\end{array}$ & $\begin{array}{l}36.5 \\
36.5 \\
38.0\end{array}$ & $\begin{array}{l}49.0 \\
47.5 \\
47.5\end{array}$ & $\begin{array}{l}41.5 \\
40.0 \\
38.5\end{array}$ & $\begin{array}{l}8.25 \\
7.85 \\
7.70\end{array}$ & $\begin{array}{l}140 \\
140 \\
140\end{array}$ & $\begin{array}{l}4.0 \\
3.5 \\
3.6\end{array}$ & $\begin{array}{l}104 \\
104 \\
103\end{array}$ & $\begin{array}{l}30.9 \\
31.0 \\
30.5\end{array}$ & $\begin{array}{l}1.00 \\
1.70 \\
0.93\end{array}$ \\
\hline
\end{tabular}

* Arterialized cutaneous whole blood (16). Normal values: $\mathrm{pH} 7.42 \pm 0.04 ; \mathrm{CO}_{2} 21.2 \pm 2.6 \mathrm{mMoles}$ per L.: BB (buffer base) $48.8 \pm 3.8 \mathrm{mEq}$. per L.; $\mathrm{pCO}_{2} 37.6 \pm 7.2 \mathrm{~mm}$. $\mathrm{Hg}$.

loaded with potassium in the control period, their difference between control and depletion intakes) urinary losses declined very rapidly. This impetus to renal conservation of potassium (the in the first day of depletion is shown clearly in Figure 5 where the decrement in intake corre-

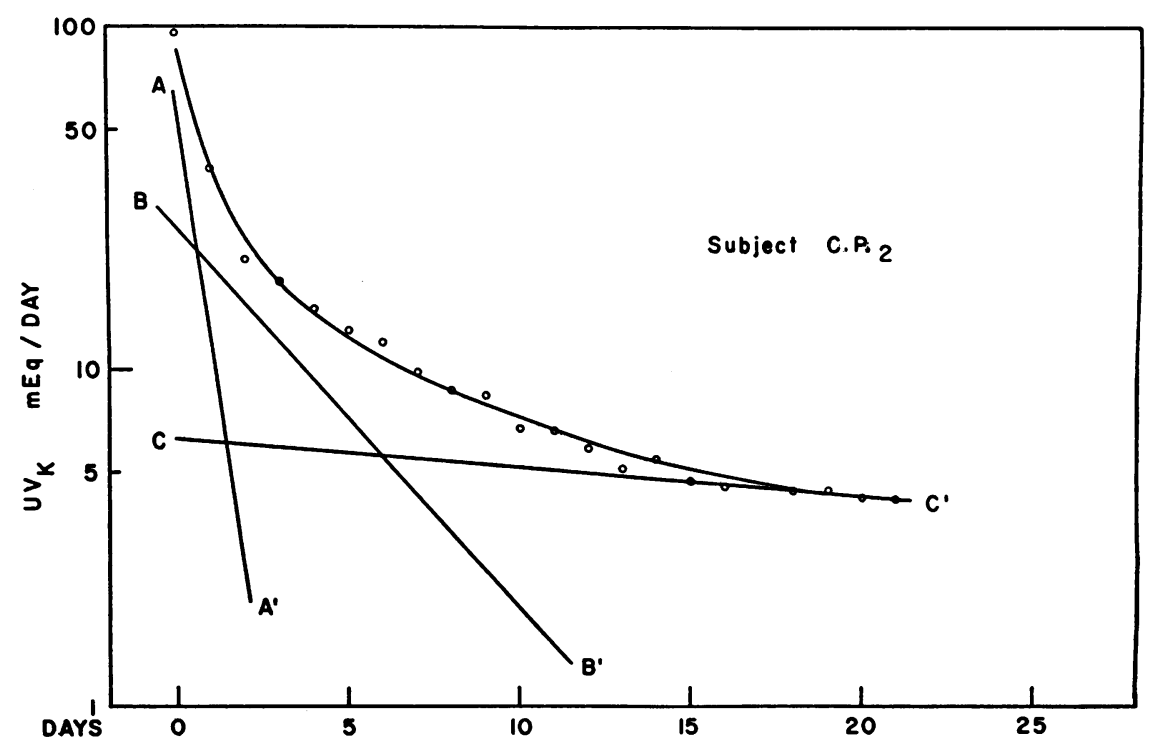

Fig. 4. The Rates of Renal Potassium Excretion During Potassium Depletion

At least three exponential rates may be derived from the curve describing the daily urinary potassium excretion during potassium depletion (Subject C. P.2): A-A $=$ (64) $\left(e^{-1.02 d}\right), B-B^{\prime}=(26)\left(e^{-0.72 d}\right)$ and $C-C^{\prime}=(6.3)\left(e^{-0.019 d}\right)$. For further discussion, see text. 
lates well with the estimated instantaneous rate of decline in urinary potassium at the end of the first day. This correlation becomes less certain at the end of the fourth depletion day and probably disappears by the end of the seventh day.

The decline in the urinary potassium content in the first three days of depletion was roughly comparable to that observed by Black and Milne (2) on similar potassium intakes. ${ }^{3}$ However, the curve for urinary potassium could not be described by a single exponential function, as in their study. An analysis of the curve for the subject depleted for the longest period, C. P.2, 21 days, showed that it could be reasonably well described as the sum of three exponential functions (Figure 4). This analysis does not necessarily imply the identification of three physiological functions in the body which determine urinary potassium content under the circumstances of the study, but it does serve as a convenient way to describe the shape of the curve.

The rate of renal potassium conservation was slower than that for sodium, as previously described (2). The improvement in potassium conservation during a simultaneous reduction in sodium intake is certainly small, if significant at all (Figure 2, curves $A-\mathrm{A}^{\prime}$ and $\mathrm{B}-\mathrm{B}^{\prime}$ ). Sodium, however, appears to be conserved much more effectively during a simultaneous reduction in potassium intake (Figure 2, curves $C-C^{\prime}$ and $\left.\mathrm{D}-\mathrm{D}^{\prime}\right)$. These curves emphasize the greater effectiveness of renal conservation of sodium as compared to that for potassium.

No other attempts were made to study changes

\footnotetext{
${ }^{3}$ Black and Milne (2) measured the rate at which potassium conservation becomes effective by evaluating $\alpha$ in the following expression:

$$
Q_{t}=Q_{0} \times e^{-\alpha t}
$$

in which $Q_{t}$ is the potassium output on day $t$, and $Q_{0}$ is the initial potassium output. This equation for the data of Black and Milne is:$$
Q_{t}=106 \times e^{-0.305 t}
$$

This equation for Subjects J. B. and R. A. is :

$$
Q_{\mathrm{t}}=103 \times \mathrm{e}^{-0.414 \mathrm{t}}
$$

The value of $\alpha$ obtained for our subjects indicates a more rapid rate of potassium conservation compared to those of Black and Milne. This difference may not be significant. The $\alpha \mathrm{K}$ of 0.414 obtained for our studies corresponds more closely to the $\alpha \mathrm{Na}$ of 0.44 obtained by Black and Milne from a sodium conservation study (2).
}

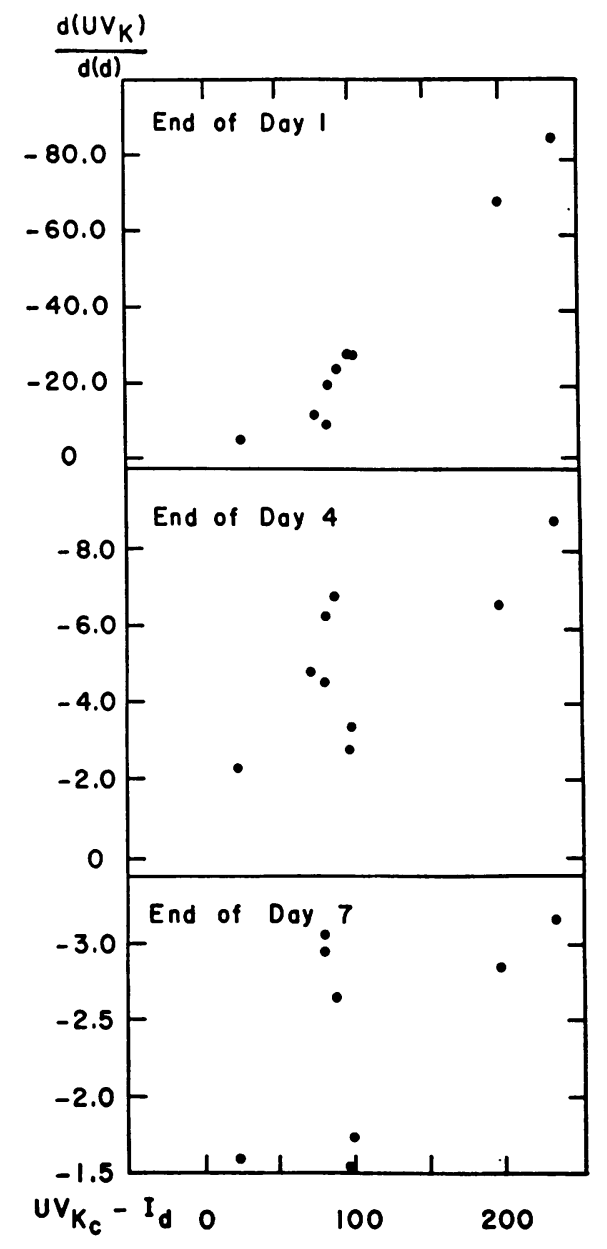

Fig. 5. The Daily Rate of Potassium Excretion During the Potassium Depletion Period

The instantaneous rate of decline of urinary potassium excretion, $\frac{d\left(U V_{K}\right)}{d \text { (days) }}$, is plotted as a function of the average of the urinary potassium excretion for the last three days of the control period, $\mathrm{UVK}_{\mathrm{C}}$, minus the potassium intake during the depletion period, $I_{d}$. The quantity $U V_{K_{C}}-I_{d}$ is taken as an index of the change in potassium load between the control and the depletion periods. The differential $\frac{d\left(U V_{K}\right)}{d(\text { days })}$ was derived by differentiation of exponential curves fitted to the data of daily urinary potassium loss as in Figure 4. Any correlation existing between these two variables becomes less apparent the farther along in the depletion period the observation is made.

in renal function which might follow potassium depletion. Whatever impairment of concentrating power and resulting polyuria might have been found as described so well in rat studies by Hollander and associates (18) was obscured by the large fluid intakes required by the study 
design. No significant changes in creatinine clearance were found.

Although no direct information is provided by these studies on mechanisms regulating the loss of potassium in stools during reduced potassium intake, these data emphasize how important this route of loss was in the absence of diarrhea. Despite a tendency for conservation of potassium in the gut as well as in the kidney, the daily loss of between 2 and $25 \mathrm{mEq}$. of potassium in stools made stool loss a very substantial fraction of the total loss (Table VI). In Subject C. P.2, for example, daily stool loss was about $10 \mathrm{mEq}$. when urinary potassium was only about $5 \mathrm{mEq}$. per day. A marked increase in the fluidity of the stool is associated with an increase in stool potassium content (19). In each subject there was little variation in the percentage of stool solids, but there was a considerable variation among subjects (Table V). This variation was not related, though, to the potassium content of these nondiarrheal stools and one can only conclude that a wide variation of stool potassium content can exist independently of fluidity in normal subjects.

Studies of Gardner, MacLachlan, Terry, McArthur and Butler (20) show that potassium deficiency may increase fecal loss of chloride in rats. Our human subjects did not show this phenomenon, but it must be conceded that the degree of their depletions were much smaller relative to body weight than were those of the rats. Perhaps the most surprising finding was the very modest degree of metabolic alkalosis which developed in any of these studies. The subject, C. P.2, with the largest potassium deficit, $502 \mathrm{mEq}$. (351 mEq. when corrected for nitrogen balance), showed a rise in venous serum $\mathrm{CO}_{2}$ content of only $3.5 \mathrm{mMoles}$ per L. from a control level of 26.1 during his depletion period of 21 days. His arterial whole blood $\mathrm{pH}$ rose from 7.39 to only 7.43. Because in a previous study of experimental potassium depletion in man (2) more striking rises in serum $\mathrm{CO}_{2}$ were noted when sodium loading accompanied the depletion (rises to 36.1 and $33.4 \mathrm{mEq}$. per L.), two of our subjects were given sodium loads of $350 \mathrm{mEq}$. per day. With potassium depletions comparable in degree to those of Black and Milne (2), one of the subjects (R. A.) developed a comparable rise in serum $\mathrm{CO}_{2}(+7.0 \mathrm{mEq}$. per L.) but at a lower level (final $\mathrm{CO}_{2}, 30.1$ ). The second subject (J. B.) showed not even a tendency toward metabolic alkalosis. The authors conclude that human subjects must show a great variability in susceptibility to metabolic alkalosis in the presence of a pure potassium depletion and agree with Moore and co-workers (21) that sodium loads must play a very significant part in the appearance of the alkalosis. A subsequent paper discusses the acid-base problem in experimental potassium depletion in greater detail (22).

A final comment must be made on the failure of the arterialized cutaneous blood total $\mathrm{CO}_{2}$ values to parallel the venous serum $\mathrm{CO}_{2}$ in Subjects C. P.2 and R. A. (Table VIII). The authors do not believe that technical errors account for this failure but the only explanation they can offer is a speculative one. The red cell, in potassium depletion, may show a replacement of potassium lost by a sodium gain (23) like that shown by skeletal muscle (24). Gardner, MacLachlan and Berman have shown that this change in skeletal muscle composition is accompanied by a decrease in bicarbonate content (25). If a like change in red cell bicarbonate took place in the subjects under discussion, these decreases could have cancelled out or masked the rises in serum $\mathrm{CO}_{2}$, inasmuch as the cutaneous blood analyses were done on whole blood.

\section{SUMMARY AND CONCLUSIONS}

Fourteen balance studies were done on 11 normal male subjects depleted of potassium by dietary deprivation of the ion. The basic study plan consisted of a control period lasting three to eight days and a succeeding depletion period lasting 6 to 21 days during which the potassium intake was set at one of three levels: 25 to 27 , 14 to 16 or $<1 \mathrm{mEq}$. per day. During the depletion period the effects of the following diet programs on the urinary and fecal potassium loss were observed: 1) ingestion of a greatly augmented sodium intake through the entire study; 2) ingestion of sodium and potassium entirely with chloride or with chloride and bicarbonate in a ratio of $3: 1 ; 3)$ ingestion of a low intake of sodium of $14 \mathrm{mEq}$. per day during the control period; and 4) ingestion of a high intake of 
potassium in excess of $300 \mathrm{mEq}$. per day during the control period.

The rate of urinary excretion of potassium: 1) during the first few days of depletion varied directly with the difference between the urinary potassium of the control period and the potassium intake in the depletion period; 2) varied directly with the level of potassium intake throughout the depletion period; but 3) clearly exceeded the intake when the latter was $1 \mathrm{mEq}$. or less per day ; 4) declined at two or more exponential rates when the potassium intake was $<1$ mEq. per day ; 5) was increased by sodium loading at the lowest level of potassium intake; and 6) was not affected by the association of chloride alone versus chloride plus bicarbonate with the total cation ingested.

Fecal potassium accounted for 11 to 59 per cent of the total loss of potassium when the intake of potassium was less than $1 \mathrm{mEq}$. per day. Cumulative negative balances of potassium varied with level of intake and duration of study reaching a maximum of $-502 \mathrm{mEq}$. or $6.4 \mathrm{mEq}$. per $\mathrm{Kg}$. in one subject on less than $1 \mathrm{mEq}$. per day for 21 days.

The rate of urinary excretion of sodium on a low sodium intake was diminished when the concomitant potassium intake was low. The rate of excretion of titratable acid plus ammonium ion remained essentially unchanged or decreased slightly during potassium depletion and the urine $\mathrm{pH}$ rose. Urinary total $\mathrm{CO}_{2}$ and bicarbonate increased in the one subject in which it was measured and the calculated total excretion of hydrogen diminished relative to dietary intake.

Metabolic alkalosis was an inconstant finding and when present was of a minor degree.

It is concluded: 1) that the degree of renal conservation of potassium $a$ ) is related to the degree of change in intake of the ion from predeprivation levels and to the duration of the deprivation, $b$ ) is diminished by an increased intake of sodium, and $c$ ) is less efficient than the renal conservation of sodium under conditions of comparable deprivation of the respective ions; 2) that with prolonged deprivation of potassium the fecal loss of the ion, though absolutely decreasing, becomes a progressively larger factor in the development of the negative potassium balance; and 3) that a marked degree of extra- cellular metabolic alkalosis is not an obligatory accompaniment to potassium depletion of the normal human subject.

\section{ACKNOWLEDGMENTS}

The authors wish to thank Dr. J. Russell Elkinton, Dr. J. R. Brobeck and Dr. F. C. Wood for their guidance and generous support during this study.

We are indebted to Mrs. Claire Tissari, Mrs. Dolores Bluemle, Mrs. Lidia Kosolapove, Mrs. Katherine Wishnevski and Mr. James Mitchell of the laboratory of the Chemical Section for most of the chemical analyses; to Mrs. Cynthia Henderson, Miss Helen Merton, Mrs. Patricia McCreary and the other members of the nursing staff of the Metabolic Unit; to Mrs. Marie Bunting, Miss Mary Demyan and Miss Nancy Sweeney for dietetic service, and to Dr. John Reinhold and the William Pepper Laboratory for technical advice and assistance in carrying out certain chemical procedures.

\section{REFERENCES}

1. Tarail, R., and Elkinton, J. R. Potassium deficiency and the role of the kidney in its production. $\mathrm{J}$. clin. Invest. 1949, 28, 99.

2. Black, D. A. K., and Milne, M. D. Experimental potassium depletion in man. Clin. Sci. 1952, 11, 397.

3. Womersley, R. A., and Darragh, J. H. Potassium and sodium restriction in the normal human. $\mathrm{J}$. clin. Invest. 1955, 34, 456.

4. Fourman, P. The ability of the normal kidney to conserve potassium. Lancet 1952, 1, 1042.

5. Reimer, A., Schoch, H. K., and Newburgh, L. H. Certain aspects of potassium metabolism. J. Amer. diet. Ass. 1951, 27, 1042.

6. Blahd, W. H., and Bassett, S. H. Potassium deficiency in man. Metabolism 1953, 2, 218.

7. Levey, S., Babb, L. I., Krieger, H., and Abbott, W. E. Potassium losses in surgical patients maintained on potassium-deficient diets. Fed. Proc. 1953, 12, 238.

8. Freyberg, R. H., and Grant, R. L. Loss of minerals through the skin of normal humans when sweating is avoided. J. clin. Invest. 1937, 16, 729.

9. Arn, K. D., and Reimer, A. Minimal sodium losses through the skin. J. clin. Invest. 1950, 29, 1342.

10. Wallace, W. M., Holliday, M., Cushman, M., and Elkinton, J. R. Application of internal standard flame photometer to analysis of biologic material. J. Lab. clin. Med. 1951, 37, 621.

11. Franco, V., and Klein, B. The microdetermination of chlorides in serum and spinal fluid. J. Lab. clin. Med. 1951, 37, 950.

12. Peters, J. P., and Van Slyke, D. D. Quantitative Clinical Chemistry, Vol. II, Methods. Baltimore, Williams and Wilkins Co., 1932. 
13. Folin, O., and Bell, R. D. Applications of a new reagent for the separation of ammonia. I. The colorimetric determination of ammonia in urine. J. biol. Chem. 1917, 29, 329.

14. Stadie, W. C., and Van Slyke, D. D. Studies of acidosis. XV. Carbon dioxide content and capacity in arterial and venous blood plasma. J. biol. Chem. 1920, 41, 191.

15. Bonsnes, R. W., and Taussky, H. H. On the colorimetric determination of creatinine by the Jaffe reaction. J. biol. Chem. 1945, 158, 581.

16. Singer, R. B., and Hastings, A. B. An improved clinical method for the estimation of disturbances of the acid-base balance of human blood. Medicine 1948, 27, 223.

17. Elkinton, J. R., and Danowski, T. S. The Body Fluids: Basic Physiology and Practical Therapeutics. Baltimore, Williams and Wilkins Co., 1955 , p. 83.

18. Hollander, W., Jr., Winters, R. W., Williams, T. F., Holliday, M., Oliver, J., and Welt, L. G. The renal concentrating defect in potassium depleted rats (abstract). J. clin. Invest. 1956, 35, 713.

19. Holt, L. E., Courtney, A. M., and Fales, H. L. The chemical composition of diarrheal as compared with normal stools in infants. Amer. J. Dis. Child. 1915, 9, 213.
20. Gardner, L. I., MacLachlan, E. A., Terry, M.' L., McArthur, J. W., and Butler, A. M. Chloride diarrhea and systemic alkalosis in potassium deficiency. Fed. Proc. 1950, 8, 201.

21. Moore, F. D., Boling, E. A., Ditmore, H. B., Jr., Sicular, A., Teterick, J. E., Ellison, A. E., Hoye, S. J., and Bell, M. R. Body sodium and potassium. V. The relationship of alkalosis, potassium deficiency and surgical stress to acute hypokalemia in man. Metabolism 1955, 4, 379.

22. Huth, E. J., Squires, R. D., and Elkinton, J. R. Experimental potassium depletion in normal human subjects. II. Renal and hormonal factors in the development of extracellular alkalosis during depletion. J. clin. Invest. 1959, 38, 1149.

23. Kennedy, T. J., Jr., Winkley, J. H., and Dunning, M. F. Gastric alkalosis with hypokalemia. Amer. J. Med. 1949, 6, 790.

24. Darrow, D. C., Schwartz, R., Iannucci, J. F., and Coville, F. The relation of serum bicarbonate concentration to muscle composition. J. clin. Invest. 1948, 27, 198.

25. Gardner, L. I., MacLachlan, E. A., and Berman, H. Effect of potassium deficiency on carbon dioxide, cation, and phosphate content of muscle. With a note on the carbon dioxide content of human muscle. J. gen. Physiol. 1952, 36, 153. 